\title{
Review
}

\section{The Habermas/Rawls debate}

James Gordon Finlayson

New York, Columbia University Press, 2019, xi + 294pp., ISBN

9780231164108

Contemporary Political Theory (2021) 20, S140-S143. https://doi.org/10.1057/s41296020-00418-0; published online 1 July 2020

James Gordon Finlayson's excellent study on the Habermas-Rawls debate begins by noting the widespread sense of disappointment after their 1995 exchange in the Journal of Philosophy. Some thought Habermas had misunderstood Rawls's project, especially its turn to political liberalism. Others thought that, despite his expression of admiration, Rawls did not seriously engage Habermas's own position. In any event, for many the exchange was a missed opportunity for a serious engagement between two of the most influential philosophers of the past century.

Finlayson offers various explanations for this failure, but, more importantly, he argues that once some of the initial misunderstandings are cleared away, the terms for a serious engagement remain. One significant misunderstanding, for which Habermas was partly responsible, concerned the comparison between Rawls's theory of justice - especially the original position - and Habermas's own discourse ethics were these competing accounts of social justice or rival attempts to characterize or operationalize the standpoint of moral impartiality? As Finlayson points out, this ambiguity continued to influence subsequent discussion of their work, including Habermas's own assessment of Rawls in his contribution to the Journal (pp. 74-76). Indeed, one of Finlayson's central claims is that Habermas repeatedly returns to an 'invidious comparison' (pp. 109, 201) between Habermas's own moral theory and Rawls's political conception of justice - a comparison that is misguided since it fails to distinguish between these two importantly different tasks.

Once these misunderstandings are removed, what are the remaining terms on which a significant debate between these thinkers can be pursued? Finlayson focuses primarily on two, though both have further ramifications. The first is Rawls's charge that Habermas's theory is a 'comprehensive doctrine' that Rawls's political turn avoids (pp. 10, 243). The second is Habermas's criticism that Rawls's theory of justice is too narrowly moral (despite his political turn), both in its neglect of the role of law in modern society and in its focus on the moral virtues of

(C) 2020 Springer Nature Limited. 1470-8914 Contemporary Political Theory Vol. 20, S3, S140-S143 
individuals, together with the background moral-political culture that informs them (pp. 173, 240). These two criticisms are also reflected in Finlayson's own conclusion that Habermas's approach is largely explanatory and 'normatively light,' while Rawls's view is too normative and 'sociologically light' (p. 242). I do not take issue with this broad characterization, but, in my opinion, Finlayson overemphasizes these differences and concludes that they are engaged in quite distinct projects that barely intersect with one another - in their later work as well as in their earlier work (pp. 50, 250 n. 9, 233, 242).

Of course it is not disputed that Rawls is engaged in normative political theory. Yet, as Finlayson notes, though justice as fairness is a moral conception, it is also a political conception. Here Finlayson raises the difficult question of what is meant by 'political' and whether Rawls and Habermas share a sufficiently similar conception (pp. 173, 183, 196). But Finlayson, like Habermas, mischaracterizes Rawls's project here. As I have argued elsewhere, Rawls's project can be viewed as a 'practice-based' approach, and his focus on the basic structure of society - and the expectations generated through participation in it - figures prominently in both his early and late work (Baynes, 2014). Thus, Rawls also 'reconstructs' the normative assumptions of this practice, and his later emphasis on the 'fundamental ideas' implicit in liberal political culture equally emphasizes this idea of a fair system of social cooperation between free and equal citizens. I am not as persuaded as Finlayson is by Jonathan Quong's argument that these ideas are the proper focus of an overlapping consensus (pp. 128, 184), but they are both correct that Rawls begins with the assumption that these ideas must be shared and that he does not offer further moral argument for them. This is close to the source of Habermas's own criticism that Rawls's notion of public justification relies on a 'lucky convergence' between reasonable comprehensive views - what Finlayson calls his serendipity argument (p. 139). However, I do not think this is quite right either. Rawls states that the political conception must be political in the right way, and this would prohibit a mere modus vivendi. Rather Rawls here evinces a liberal hope that all reasonable citizens can find their way to support the political conception, but the fact that they do is not what makes the conception right. At this point Rawls and Habermas basically converge on a 'Kantian pragmatism' that appeals to a 'comon human reason' or 'democratic common sense' when other arguments run out because of the limits imposed by the fact of reasonable pluralism itself (Baynes, 2016, pp. 175, 212).

Finlayson's discussion of Habermas's views reflects a deep engagement with his work, and I have learned much from his reading. He rightly argues that while Habermas's theory is comprehensive in the sense that it draws upon a great variety of theories, it is not comprehensive in a way that is objectionable (p. 178). Habermas, like Rawls, argues that the principles structuring the liberal democratic state must be neutral or 'freestanding' with respect to comprehensive moral and religious views (pp. 96, 177). Finlayson also emphasizes that Habermas's theory

(c) 2020 Springer Nature Limited. 1470-8914 Contemporary Political Theory Vol. 20, S3, S140-S143 S141 
rests heavily on a functionalist account of law and the state that, as part of his understanding of societal modernization, shifts the weight of social integration away from a shared moral or religious worldview. There is much in Habermas to support this reading, but a functional argument cannot substitute for normative justification - indeed, this is one criticism Finlayson later turns against Habermas (p. 242). More importantly, however, I believe that Finlayson misunderstands Habermas's own views about a 'reconstructive' approach. Finlayson states that this is a non-normative inquiry open to empirical testing and so not to be confused with the normative theorizing of Rawls or Dworkin (pp. 43, 88, 233). This is partially correct, and Habermas generally insists on a distinction between his contributions as a theorist and his contributions as a participant (mostly in the form of editorials and short essays). But as a passage Finlayson quotes indicates (p. 80), reconstructive inquiry is normative and seeks to make explicit the norms implicit in social practices (not unlike Rawls on a practice-based reading). This is not a minor interpretive issue, because it leads Finlayson to read Habermas's reconstructive approach to democracy and the system of rights in an exclusively functionalist way and unable to account for the 'moral content' of his schema of rights (pp. 93f.). It also leads him to question what he calls the 'moral permissibility constraint,' which for Habermas means that a legitimate legal order cannot violate basic moral principles (pp. 91-92, 108, 167). To be sure, the question of the relation between law and morality is especially difficult to parse in Habermas's theory - elsewhere, for example, Finlayson (somewhat surprisingly) says that Habermas's theory presupposes discourse ethics (pp. 177, 181, 244). My own view is that the co-originality of public and private autonomy is not simply a procedural maneuver but must entail some substantive moral content - in the case of private autonomy, roughly equivalent to what Rawls includes in his equal liberty principle. The moral egalitarianism Habermas frequently invokes, however, cannot be limited to any specific (comprehensive) account, just as it cannot be ignored. To capture this idea - and avoid an over-alignment of Habermas with the natural law tradition - I proposed a 'dialectic of moral and political constructivism' (Baynes, 2016, p. 124). It also moves the positions of Rawls and Habermas closer to one another. For both, legitimacy requires a 'harmonization' with morality, but they can only express a rational hope for this if they do not wish to violate their own commitment to the 'freestanding' political domain.

Finlayson's sharper contrast of the two theorists is again evident in the final chapter on the place of religion in the public sphere. He suggests that since they are operating at very different levels - one in normative theory and the other in nonnormative reconstruction - it is a confusion to see Habermas's translation proviso, which is described as an 'institutional filter' between the formal and informal public sphere, as an attempt to address the same objections about unfair burdens that had been posed to Rawls (pp. 233-234). Whereas Rawls sought to clarify the civic obligation of citizens, Habermas defends the legal right of citizens to make

S142 (c) 2020 Springer Nature Limited. 1470-8914 Contemporary Political Theory Vol. 20, S3, S140-S143 
full use of their religious liberty. But I think this again slightly mischaracterizes both positions. Rawls also thinks civil society is 'wild and anarchic' but that nonetheless there is a civic duty, at least in the more narrow but still informal political public sphere, to use public reason. This must also be Habermas's position. The institutional filter cannot be only a functional mechanism, as it is an obligation that falls on citizens and 'follows from' the ethics of democratic citizenship and a demanding notion of toleration (Habermas, 2011, p. 372). Contrary to Finlayson's interpretation, it is not simply the consequence of processes of social modernization - and so not a duty of civility. This indicates again, I think, that despite some support in Habermas's remarks, Finlayson's distinction between reconstructive science as non-normative, and normative political theory, is not the best interpretation of Habermas's own position.

Finlayson insightfully discusses many other topics raised in the HabermasRawls debate that I cannot pursue here, such as their competing understandings of public reason and its basis. He also brings their respective claims regarding the autonomy of the political domain into proximity with more recent debates on political realism when he notes that, for both, 'justification in political theory just is political justification' (p. 242). In sum, Finlayson's deep engagement with this debate has much to offer, even to those who might not be as intrigued as he and I are, by the question, 'why Habermas and Rawls?' (p. 246).

\section{References}

Baynes, K. (2014) Rawls and critical theory. In: D. Reidy and J. Mandle (eds.) A Companion to Rawls. New York: Wiley.

Baynes, K. (2016) Habermas. New York: Routledge.

Habermas, J. (2011) Reply. In: Habermas and Rawls: Disputing the Political. New York: Routledge.

Publisher's Note Springer Nature remains neutral with regard to jurisdictional claims in published maps and institutional affiliations.

Kenneth Baynes

Syracuse University, Syracuse, NY 13244, USA krbaynes@syr.edu

(c) 2020 Springer Nature Limited. 1470-8914 Contemporary Political Theory Vol. 20, S3, S140-S143 S143 